\title{
IMPLEMENTASI MODEL PEMBELAJARAN KOOPERATIF TIPE TEAM ACCELERATED INSTRUCTION GUNA MENINGKATKAN MOTIVASI BELAJAR AKUNTANSI
}

\section{IMPLEMENTATION COOPERATIVE LEARNING MODEL TEAM ACCELERATED INSTRUCTION TO IMPROVING ACCOUNTING LEARNING MOTIVATION}

\author{
Oleh : \\ Gandes Aknissholikah \\ Mahasiswa Jurusan Pendidikan Akuntansi Universitas Negeri Yogyakarta \\ gandes.aniss@gmail.com \\ $\underline{\text { Sukanti }}$ \\ Starf Pengajar Jurusan P. Akuntansi UNY
}

\begin{abstract}
Abstrak
Penelitian ini bertujuan untuk meningkatkan Motivasi Belajar Akuntansi pada Kompentensi Dasar Dana Kas Kecil Siswa Kelas X Akuntansi 3 SMK Negeri 1 Godean Tahun Ajaran 2013/2014 dengan Implementasi Model Pembelajaran Kooperatif Tipe Team Accelerated Instruction (TAI) dan mengetahui Respon Siswa terhadap Implementasi Model Pembelajaran Kooperatif Tipe Team Accelerated Instruction (TAI). Penelitian ini merupakan penelitian tindakan kelas (PTK) dengan subjek penelitian siswa kelas X Akuntansi 3 SMK Negeri 1 Godean Tahun Ajaran 2013/2014 yang berjumlah 32 siswa. Penelitian ini dilaksanakan dalam bentuk kolaboratif dan partisipatif yang dilaksanakan dalam dua siklus. Pengumpulan data penelitian ini dilakukan dengan observasi dan angket. Analisis data yang dilakukan adalah analisis data deskriptif kuantitatif dengan persentase yang dilakukan dengan menghitung skor Motivasi Belajar Akuntansi, menyajikan data dan penarikan kesimpulan. Berdasarkan hasil penelitian dapat disimpulkan bahwa Implementasi Model Pembelajaran Kooperatif Tipe Team Accelerated Instruction (TAI) dapat meningkatkan Motivasi Belajar Akuntansi siswa kelas X Akuntansi 3 SMK Negeri 1 Godean Tahun Ajaran 2013/2014 yang dibuktikan dengan adanya peningkatan persentase skor Motivasi Belajar Akuntansi dari sebelum Implementasi Model Pembelajaran Kooperatif Tipe Team Accelerated Instruction (TAI) sebesar 69,38\% meningkat sebesar $8,02 \%$ atau diperoleh skor sebesar $77,40 \%$ di siklus I. Selanjutnya dari siklus I ke siklus II juga meningkat sebesar $7,78 \%$ atau diperoleh skor sebesar $85,18 \%$ di siklus II. Selain itu berdasarkan angket yang didistribusikan kepada siswa dapat disimpulkan pula bahwa terjadi peningkatan skor Motivasi Belajar Akuntansi siswa dari siklus I ke siklus II sebesar 6,99\% dimana skor pada siklus I sebesar 76,14\% meningkat menjadi 83,13\% pada siklus II. Di samping itu, hasil angket respon siswa menunjukkan bahwa siswa kelas X Akuntansi 3 memberikan respon yang sangat positif terhadap Implementasi Model Pembelajaran Kooperatif Tipe Team Accelerated Instruction (TAI) pada pembelajaran Akuntansi.
\end{abstract}

Kata Kunci: Pembelajaran kooperatif, TAI, Motivasi Belajar Akuntansi.

\begin{abstract}
This research is aims to Improve Accounting Learning Motivation in Cash Fund Small Basic Competence through Implementation Cooperative Learning Model Team Accelerated Instruction (TAI) X Accounting Class 3 SMK NEGERI 1 GODEAN Academic Year 2013/2014. This research is Classroom Action Research which subject is students from X Accounting Class 3 SMK NEGERI 1 GODEAN Academic Year 2013/2014 who have 32 students. This study was conducted in a collaborative and participatory conducted in two cycles. Research data collection was conducted by observation and questionnaires. Data analysis is descriptive quantitative data analysis is done by
\end{abstract}


calculating the percentage of scores Motivation Accounting, presenting data and drawing conclusions. Based on the result of the research concluded that Implementation Cooperative Learning Model Team Accelerated Instruction (TAI) can improve Accounting Learning Motivation student from X Accounting Class 3 SMK NEGERI 1 GODEAN Academic Year 2013/2014 evidenced by the increase in the percentage of scores Accounting Learning Motivation before Implementation Cooperative Learning Model Team Accelerated Instruction (TAI) amounted to of $69.38 \%$ or an increase of $8.02 \%$ obtained a score of $77.40 \%$ in cycle I. Furthermore, from the first cycle to the second cycle is also increased by $7.78 \%$ or obtained a score of $85.18 \%$ in the second cycle. Also based on a questionnaire distributed to students it can be concluded that an increase of scores Accounting learning motivation students from the first cycle to the second cycle of $6.99 \%$ in the first cycle in which a score of $76.14 \%$ increased to $83.13 \%$ in the second cycle. In addition, the results of student questionnaire responses showed that the students of class $X$ Accounting 3 gave a very positive response to the Implementation of Cooperative Learning Model Type of Team Accelerated Instruction (TAI) to study Accounting.

Keywords: cooperative learning, TAI, Accounting Learning Motivation.

\section{PENDAHULUAN}

Pendidikan merupakan suatu cara untuk membentuk sumber daya manusia yang berkualitas guna mendukung tercapainya tujuan pembangunan nasional. Proses pendidikan terjadi apabila ada interaksi antar komponen pendidikan, artinya saling berhubungan secara fungsional dalam kesatuan terpadu. Berhasil atau gagalnya pencapaian tujuan pendidikan itu amat bergantung pada proses belajar yang dialami siswa baik ketika ia berada di sekolah maupun di lingkungan rumah atau keluarganya sendiri. Menurut Slameto (2010: 2) belajar adalah suatu proses usaha yang dilakukan seseorang untuk memperoleh suatu perubahan tingkah laku yang baru secara keseluruhan, sebagai hasil pengalamannya sendiri dalam interaksi dengan lingkungannya.

$$
\text { Keberhasilan belajar siswa }
$$

diwujudkan dalam bentuk nilai. Dalam mendapatkan nilai tersebut dipengaruhi oleh berbagai faktor baik dari dalam maupun dari luar diri siswa. Salah satu faktor intern dan ekstern yang mempengaruhi prestasi belajar akuntansi adalah motivasi belajar siswa dan model mengajar guru. Motivasi merupakan salah satu faktor yang dapat meningkatkan kualitas pembelajaran karena peserta didik akan belajar dengan sungguh-sungguh apabila memiliki motivasi tinggi (Mulyasa, 2007: 174). Dengan demikian, guru dituntut menciptakan proses pembelajaran yang menarik dan bermutu yang dapat memotivasi dan meningkatkan prestasi belajar siswa khususnya dalam mendiskripsikan administrasi dana kas kecil pada mata pelajaran akuntansi.

Model mengajar guru merupakan cara guru dalam memberikan materi pembelajaran kepada peserta didik agar peserta didik dapat memahami dan meresapi materi pelajaran yang disampaikan guru. Model mengajar guru yang menimbulkan siswa pasif atau tidak melakukan banyak aktivitas dan menimbulkan kejenuhan untuk belajar dalam proses pembelajaran, seperti metode ceramah akan menyulitkan guru dalam membangkitkan motivasi siswa. Menurut Muhibbin Syah (2010: 165), kejenuhan belajar dapat melanda siswa apabila siswa telah kehilangan motivasi belajarnya. Dalam menciptakan proses pembelajaran 
yang baru dan tidak monoton diperlukan adanya sebuah model pembelajaran yang menerapkan perpaduan siswa dan guru serta memberikan motivasi pada siswa untuk meningkatkan aktivitas dan prestasi belajar akuntansi siswa. Salah satunya adalah model pembelajaran kooperatif (cooperative learning). Pembelajaran kooperatif merupakan bentuk pembelajaran dengan cara siswa belajar dan bekerja dalam kelompok-kelompok kecil secara kolaboratif yang anggotanya terdiri dari empat sampai enam orang dengan struktur kelompok yang bersifat heterogen (Rusman, 2010: 202).

TAI merupakan salah satu pembelajaran kooperatif. Model pembelajaran kooperatif TAI ini sering pula dimaknai sebagai Team Assisted Individualization.

Model pembelajaran kooperatif tipe TAI merupakan pembelajaran kooperatif yang pada pelaksanaannya siswa dibagi ke dalam kelompok-kelompok kecil yang heterogen. Salah satu poin penting yang harus diperhatikan untuk membentuk kelompok yang heterogen di sini adalah kemampuan akademik siswa. Masingmasing kelompok dapat beranggotakan 4-5 orang siswa. Setiap siswa secara individual belajar materi pembelajaran yang sudah dipersiapkan oleh guru. Hasil belajar individual dibawa ke kelompok-kelompok untuk didiskusikan dan saling dibahas oleh anggota kelompok. Semua anggota kelompok bertanggung jawab atas keseluruhan jawaban sebagai tanggung jawab bersama.

Berdasarkan hasil observasi pada tanggal 18 Januari 2014 yang dilakukan di kelas X Akuntansi 3 SMK Negeri 1 Godean diketahui bahwa motivasi belajar siswa masih rendah dalam mengikuti mata pelajaran Akuntansi. Observasi dilakukan pada saat pembelajaran Akuntansi berlangsung. Hal tersebut dapat dilihat dari 32 siswa kelas X Kompetensi Kejuruan Akuntansi 3, hanya 7 siswa atau 21,86\% siswa yang aktif bertanya kepada guru, 22 siswa atau $68,75 \%$ siswa tidak mendengarkan penjelasan dari guru dan hanya mengobrol dengan teman atau melakukan kegiatan di luar materi pembelajaran, 17 siswa atau 53,1\% siswa mencontek teman saat mengerjakan tugas dan 28 siswa atau $87,5 \%$ siswa tidak menyelesaikan tugas yang diberikan oleh guru dan lama mengerjakannya. Selain itu, saat mengerjakan tugas - tugas rutin 29 siswa atau 90,6\% siswa terlihat tidak bersemangat untuk mengerjakan soal. 28 siswa atau $87,5 \%$ bosan dengan pelajaran dan sudah tidak fokus lagi mendengarkan atau mengerjakan tugas dari guru setelah jam-jam terakhir pelajaran.

Penggunaan model mengajar yang konvensional dan teacher centered masih banyak diterapkan oleh guru-guru mata pelajaran Akuntansi di SMK Negeri 1 Godean. Tingginya intensitas penggunaan model ceramah yang dilakukan oleh guruguru mata pelajaran Akuntansi di SMK Negeri 1 Godean menjadikan siswa tidak melakukan banyak aktivitas, sehingga siswa banyak yang bosan dengan pembelajaran Akuntansi. Rendahnya aktivitas siswa membuat siswa cepat bosan sehingga motivasi belajar siswa kurang. Hal ini akan berpengaruh terhadap prestasi belajar siswa. Berdasarkan latar belakang masalah di atas, maka penulis tertarik untuk melakukan penelitian dengan judul "Implementasi Model Pembelajaran Kooperatif Tipe Team Accelerated Instruction (TAI) guna Meningkatkan Motivasi Belajar Akuntansi pada Kompetensi Dasar Dana Kas Kecil 
Siswa Kelas X Akuntansi 3 SMK Negeri 1 Godean Tahun Ajaran 2013/2014”.

\section{METODE PENELITIAN}

\section{Jenis Penelitian}

Penelitian ini merupakan penelitian tindakan kelas (Classroom Action Research) yang bersifat kolaborasi. Peneliti akan berkolaborasi dengan guru mata pelajaran dalam melakukan penelitian tindakan kelas yang dilaksanakan sebanyak dua siklus. Penelitian ini menggunakan model penelitian tindakan dari Kemmis dan Taggart, yaitu bentuk spiral dari siklus yang satu ke siklus berikutnya. Setiap siklus meliputi planning (rencana), action (tindakan), observation (pengamatan), dan reflection (refleksi).

\section{Waktu dan Tempat Penelitian}

Penelitian dilakukan untuk meneliti Implementasi Pembelajaran Kooperatif Tipe Team Accelerated Instruction (TAI) guna Meningkatkan Motivasi Belajar Akuntansi pada Kompetensi Dasar Dana Kas Kecil Siswa Kelas X Akuntansi 3 SMK Negeri 1 Godean Tahun Ajaran 2013/2014 yang beralamat di Kowanan, Sidoagung, Godean, Sleman, Daerah Istimewa Yogyakarta, 55564. Telp./Fax. 0274798274. Penelitian dilaksanakan meliputi tahap persiapan pada bulan NovemberDesember 2013. Tahap pelaksanaan sampai tahap pelaporan yaitu pada pada bulan Januari-Februari tahun 2014.

\section{Target/Subjek Penelitian}

Subjek penelitian ini adalah seluruh siswa kelas X Akuntansi 3 SMK Negeri 1 Godean Tahun Ajaran 2013/2014 yang berjumlah 32 siswa, sedangkan objek penelitian ini adalah Implementasi
Pembelajaran Kooperatif Tipe Team Accelerated Instruction (TAI) guna Meningkatkan Motivasi Belajar Akuntansi pada Kompetensi Dasar Dana Kas Kecil.

\section{Prosedur}

Penelitian ini dilakukan secara kolaboratif dengan guru mata pelajaran akuntansi kelas X Akuntansi 3 SMK Negeri 1 Godean. Penelitian ini dilaksanakan sebanyak dua siklus. Masing-masing siklus dilaksanakan sebanyak dua kali pertemuan. Setiap siklus terdiri dari beberapa komponen, yaitu perencanaan (planning), pelaksanaan (acting), pengamatan (observing), dan refleksi (reflecting). Adapun prosedur pelaksanaannya adalah sebagai berikut:

1. Siklus I

a. Perencanaan (Planning)

Pada tahap perencanaan peneliti menyiapkan segala sesuatu yang dibutuhkan saat pelaksanaan. Hal tersebut meliputi :

1) Menyusun Rencana Pelaksanaan Pembelajaran (RPP) menyiapkan peralatan yang dibutuhkan untuk mempelajari administrasi dana kas kecil dengan menggunakan tipe TAI.

2) Merancang materi pembelajaran dan menyiapkan peralatan yang dibutuhkan untuk mempelajari administrasi dana kas kecil yang disesuaikan dengan model pembelajaran kooperatif tipe TAI dan diseuaikan dengan situasi serta kondisi kelas yang bersangkutan.

3) Menyusun soal tes siklus pertama.

4) Menyiapkan lembar observasi, angket dan catatan lapangan yang akan digunakan. 
b. Pelaksanaan (Acting)

Apabila tahap perencanaan tindakan telah matang, selanjutnya melaksanakan rencana tersebut di kelas dengan berpedoman RPP yang telah disusun. Guru sebagai tenaga pengajar melaksanakan tindakan berdasarkan perencanaan sebelumnya, sedangkan peneliti akan melaksanakan penelitian terhadap segala kegiatan yang dilakukan siswa selama proses pembelajaran dengan menggunakan model pembelajaran kooperatif tipe TAI. Pelaksanaan ini bersifat fleksibel yang dapat dimodifikasi sewaktu-waktu sesuai dengan situasi dan kondisi serta keperluan yang terjadi di lapangan. Mengenai segala perubahan akan dicatat dalam catatan lapangan.

c. Pengamatan (Observing)

Observasi dilakukan melalui pengamatan selama proses pembelajaran berlangsung. Peneliti melakukan pengamatan dan melakukan pencatatan dalam lembar observasi dan catatan lapangan. Pengamatan dilakukan dengan melihat berbagai tindakan yang muncul selama pembelajaran dan mencerminkan aspek Motivasi Belajar Akuntansi.

d. Refleksi (Reflecting)

Refleksi dilakukan dengan diskusi bersama guru mata pelajaran akuntansi berdasarkan hasil dari tindakan siklus pertama yang tercatat dalam lembar observasi, angket, dan catatan lapangan. Berdasarkan hasil refleksi dari proses pembelajaran yang dilaksanakan pada siklus pertama, peneliti bersama dengan guru menyusun rencana pemecahan masalah dalam penggunaan model pembelajaran kooperatif tipe TAI yang terjadi dalam siklus pertama untuk memperbaiki proses pembelajaran pada siklus kedua.

2. Siklus II

Pada Siklus II ini hampir sama dengan siklus pertama, tetapi perencanaan pada siklus kedua merupakan perbaikan terhadap kekurangan yang terjadi pada siklus pertama berdasarkan refleksi yang telah dilakukan.

\section{Data, Intrumen, dan Teknik Pengum- pulan Data}

1. Pedoman Observasi

Observasi yang dilakukan membutuhkan pedoman tertulis yang memuat indikator-indikator yang akan diamati. Berdasarkan indikatorindikator yang telah ditetapkan sebelumnya maka aspek yang akan diamati yaitu tekun menghadapi tugas, ulet menghadapi kesulitan, memiliki minat terhadap pelajaran, lebih senang bekerja mandiri, cepat bosan pada tugas-tugas rutin, dapat mempertahankan pendapatnya, tidak mudah melepaskan hal yang diyakini dan senang mencari dan memecahkan masalah soal-soal.

2. Angket

Pada penelitian ini angket digunakan untuk memperoleh data tentang Motivasi Belajar Akuntansi dan Respon Siswa terhadap Model Pembelajaran Kooperatif Tipe TAI. Angket yang digunakan dalam penelitian ini berupa angket tertutup dengan 4 alternatif sehingga responden tinggal memilih jawaban yang telah 
tersedia. Angket disusun berdasarkan indikator-indikator yang akan diukur.

3. Catatan Lapangan

Catatan lapangan berupa formulir yang digunakan sebagai pencatat berita acara pelaksanaan pembelajaran dengan tipe TAI. Catatan lapangan digunakan untuk menuliskan berbagai kejadian yang berhubungan penelitian yang terjadi di dalam kelas. Kejadian dapat berupa interaksi yang terjadi antara siswa dengan guru, maupun interaksi antar siswa.

\section{Teknik Analisis Data}

Dalam penelitian ini, data yang diperoleh dari hasil observasi dan angket adalah data kuantitatif yang menunjukkan penilaian atas kemunculan kegiatan yang mencerminkan Motivasi Belajar Akuntansi siswa dan Respon Siswa terhadap Implementasi Model Pembelajaran Kooperatif Tipe TAI. Langkah - langkah yang dilakukan adalah :

1. Skor Motivasi Belajar Akuntansi Siswa Data yang diperoleh akan dianalisis untuk mengetahui persentase skor motivasi Belajar Akuntansi siswa yaitu:

$\%=\frac{\text { Skor Hasil Motivasi Belajar Akuntansi Siswa }}{\text { Skor Maksimum }} X 100 \%$

2. Skor Respon Siswa terhadap Implementasi Model Pembelajaran Kooperatif Tipe TAI.

Dalam penelitian ini skala yang digunakan dalam penilaian angket respon siswa adalah $4,3,2$, 1 . Jumlah pertanyaan dalam angket adalah 22 butir. Skor maksimal yang akan diperolah siswa adalah 88 sedangkan skor minimalnya adalah 22. Dari skor yang diperoleh dari siswa kemudian dimasukkan sesuai dengan kriteria penskoran dengan rumus sebagai berikut:

Rentang Data $=(88-22)+1=67$

Panjang Kelas $=67 / 4=16,75$

(dibulatkan menjadi 17)

Tabel 1. Skor Respon Siswa

\begin{tabular}{|c|c|}
\hline $\begin{array}{c}\text { Skor } \\
\text { peserta } \\
\text { didik }\end{array}$ & Kategori \\
\hline $72-88$ & Sangat Positif \\
\hline $55-71$ & Positif \\
\hline $38-54$ & Negatif \\
\hline $21-37$ & Sangat Negatif \\
\hline
\end{tabular}

3. Penyajian Data

Penyajian data dapat dilakukan dalam bentuk tabel, grafik, dan sejenisnya. Dari penyajian ini dapat memudahkan pembaca dalam memahami dan menafsirkan data yang diperoleh dengan benar.

4. Penarikan Kesimpulan

Penarikan kesimpulan adalah proses penarikan intisari dari sajian data yang telah terorganisir tersebut dalam bentuk pernyataan untuk menjawab rumusan masalah yang telah dirumuskan.

\section{HASIL PENELITIAN DAN PEMBA- HASAN}

1. Hasil Observasi

a. Observasi Awal

Sebelum Implementasi Model Pembelajaran Kooperatif Tipe Team Accelerated Instruction (TAI) guna Meningkatkan Motivasi Belajar Akuntansi Siswa pada Kompentensi Dasar Dana Kas Kecil Siswa Kelas X Akuntansi 3 SMK Negeri 1 Godean 
Tahun ajaran 2013/2014, peneliti melakukan observasi prasiklus pada pembelajaran akuntansi yang dilaksanakan oleh guru dengan menggunakan metode ceramah dan latihan soal. Data yang diperoleh dalam observasi prasiklus adalah sebagai berikut:

Tabel 2. Skor Motivasi Belajar Akuntansi Sebelum Penerapan Model Pembelajaran Kooperatif Tipe TAI

\begin{tabular}{|l|l|l|}
\hline No. & Indikator & Skor \\
\hline 1 & Tekun menghadapi tugas & $66,70 \%$ \\
\hline 2 & Ulet menghadapi kesulitar & $60,00 \%$ \\
\hline 3 & $\begin{array}{l}\text { Menunjukkan minat } \\
\text { terhadap mata pelajaran } \\
\text { Akuntansi }\end{array}$ & $52,60 \%$ \\
\hline 4 & $\begin{array}{l}\text { Cepat bosan pada tugas- } \\
\text { tugas rutin }\end{array}$ & $53,91 \%$ \\
\hline 5 & $\begin{array}{l}\text { Senang mencari dan } \\
\text { memecahkan masalah }\end{array}$ & $46,48 \%$ \\
\hline \multicolumn{2}{|l|}{ Skor rata-rata } & $69,38 \%$ \\
\hline
\end{tabular}

Sumber: Data primer yang diolah

Dari data di atas menunjukkan skor Motivasi Belajar Akuntansi siswa kelas X Akuntansi 3 SMK Negeri 1 Godean diperoleh skor Motivasi Belajar Akuntansi sebesar $69,38 \%$. Hal ini bermakna bahwa Motivasi Belajar Akuntansi siswa belum optimal karena belum mencapai kriteria minimum yang ditentukan yaitu $75 \%$. Kurangnya keterlibatan siswa dalam pembelajaran membuat siswa kurang tertarik dan bersemangat untuk mengikuti pembelajaran.

\section{b. Laporan Hasil Penelitian}

\section{1) Siklus $I$}

Pembelajaran Akuntansi dengan model pembelajaran kooperatif tipe TAI siklus 1 dilaksanakan sebanyak dua kali pertemuan. Dari pengamatan yang dilakukan diperoleh data sebagai berikut:

Tabel 3. Skor Motivasi Belajar Akuntansi Siswa Siklus 1

\begin{tabular}{|l|l|l|}
\hline No & Indikator & Skor \\
\hline 1 & Tekun menghadapi tugas & $78,13 \%$ \\
\hline 2 & Ulet menghadapi kesulitan & $73,96 \%$ \\
\hline 3 & $\begin{array}{l}\text { Memiliki minat terhadap } \\
\text { pelajaran }\end{array}$ & $79,17 \%$ \\
\hline 4 & $\begin{array}{l}\text { Lebih senang bekerja } \\
\text { mandiri }\end{array}$ & $85,42 \%$ \\
\hline 5 & $\begin{array}{l}\text { Cepat bosan pada tugas- } \\
\text { tugas rutin }\end{array}$ & $73,44 \%$ \\
\hline 6 & $\begin{array}{l}\text { Dapat mempertahankan } \\
\text { pendapatnya }\end{array}$ & $72,92 \%$ \\
\hline 7 & $\begin{array}{l}\text { Tidak mudah melepaskan } \\
\text { hal yang diyakini }\end{array}$ & $73,96 \%$ \\
\hline 8 & $\begin{array}{l}\text { Senang mencari dan } \\
\text { memecahkan masalah }\end{array}$ & $81,77 \%$ \\
\hline Skor Rata-rata & $77,40 \%$ \\
\hline
\end{tabular}

Sumber: Data primer yang diolah

Dari data di atas diketahui bahwa terdapat empat indikator yang belum mencapai kriteria minimal yang ditentukan dan terdapat empat indikator yang sudah mencapai kriteria minimal yang ditentukan. Skor rata-rata motivasi belajar pada siklus I sebesar 77,40\%. Dari data ini selanjutnya digunakan sebagai salah satu bahan refleksi.

Dari hasil di atas, disepakati bahwa akan dilakukan perbaikan pelaksanaan tindakan pada siklus II dimana pembelajaran dirancang menggunakan soal yang lebih 
aplikatif dan tingkat kesulitannya lebih tinggi dengan harapan siswa akan berdiskusi dengan pasangannya guna menyelesaikan soal tersebut. Guru akan memberikan tugas agar siswa belajar materi yang akan dipelajari pada pertemuan selanjutnya sehingga siswa dapat membawa hasil belajar individunya ke dalam kelompok untuk didiskusikan.

\section{2) Siklus II}

Berdasarkan hasil refleksi siklus I, maka pada siklus II peneliti berusaha memperbaiki kekurangankekurangan yang terjadi pada siklus I. Dari pengamatan yang dilakukan diperoleh data, yaitu:

Tabel 4. Skor Motivasi Belajar Akuntansi Siswa Siklus II

\begin{tabular}{|l|l|l|}
\hline No & Indikator & Skor \\
\hline 1 & Tekun menghadapi tuga & $86,46 \%$ \\
\hline 2 & $\begin{array}{l}\text { Ulet menghadapi } \\
\text { kesulitan }\end{array}$ & $84,38 \%$ \\
\hline 3 & $\begin{array}{l}\text { Memiliki minat terhada } \\
\text { pelajaran }\end{array}$ & $84,03 \%$ \\
\hline 4 & $\begin{array}{l}\text { Lebih senang bekerja } \\
\text { mandiri }\end{array}$ & $91,67 \%$ \\
\hline 5 & $\begin{array}{l}\text { Cepat bosan pada tugas- } \\
\text { tugas rutin }\end{array}$ & $84,38 \%$ \\
\hline 6 & $\begin{array}{l}\text { Dapat mempertahankan } \\
\text { pendapatnya }\end{array}$ & $79,17 \%$ \\
\hline 7 & $\begin{array}{l}\text { Tidak mudah } \\
\text { melepaskan hal yang } \\
\text { diyakini }\end{array}$ & $83,33 \%$ \\
\hline 8 & $\begin{array}{l}\text { Senang mencari dan } \\
\text { memecahkan masalah }\end{array}$ & $88,54 \%$ \\
\hline Skor Rata-rata & $85,18 \%$ \\
\hline
\end{tabular}

Sumber: Data primer yang diolah

Dilihat dari skor pada setiap indikator motivasi belajar akuntansi telah mencapai kriteria minimal yang telah ditetapkan sebelumnya yaitu sebesar $75 \%$. Kemudian jika dilihat dari skor keseluruhan juga diperoleh skor Motivasi Belajar Akuntansi yang telah melampaui kriteria minimal dimana diperoleh skor 85,18\%. Hasil penelitian siklus II menunjukkan data observasi di mana delapan indikator Motivasi Belajar Akuntansi siswa telah mencapai kriteria minimal yang telah ditentukan yaitu sebesar $75 \%$.

\section{3) Hasil Angket Motivasi Belajar Akuntansi Siklus I dan Siklus II}

Angket Motivasi Belajar Akuntansi didistribusikan pada akhir pembelajaran baik pada siklus I maupun pada siklus II dimana butir pernyataan pada angket tersebut sama. Dari angket yang telah didistribusikan ditampilkan data sebagai berikut:

Tabel 5. Data Angket Motivasi Belajar Akuntansi Siklus I dan Siklus II

\begin{tabular}{|c|c|c|c|}
\hline \multirow[b]{2}{*}{ No. } & \multirow{2}{*}{ Indikator } & \multicolumn{2}{|c|}{ Skor } \\
\hline & & Siklus 1 & Siklus 2 \\
\hline 1 & $\begin{array}{l}\text { Tekun menghadap } \\
\text { tugas }\end{array}$ & $77,34 \%$ & $84,64 \%$ \\
\hline 2 & $\begin{array}{l}\text { Ulet menghadapi } \\
\text { kesulitan }\end{array}$ & $74,48 \%$ & $83,85 \%$ \\
\hline 3 & $\begin{array}{l}\text { Memiliki minat } \\
\text { terhadap pelajaran }\end{array}$ & $80,73 \%$ & $84,11 \%$ \\
\hline 4 & $\begin{array}{l}\text { Lebih senang } \\
\text { bekerja mandiri }\end{array}$ & $88,28 \%$ & $90,32 \%$ \\
\hline 5 & $\begin{array}{l}\text { Cepat bosan pada } \\
\text { tugas-tugas rutin }\end{array}$ & $74,22 \%$ & $78,52 \%$ \\
\hline 6 & $\begin{array}{l}\text { Dapat } \\
\text { mempertahankan } \\
\text { pendapatnya }\end{array}$ & $65,89 \%$ & $79,17 \%$ \\
\hline 7 & $\begin{array}{l}\text { Tidak mudah } \\
\text { melepaskan hal } \\
\text { yang diyakini }\end{array}$ & $74,22 \%$ & $80,99 \%$ \\
\hline 8 & Senang mencari & $77,34 \%$ & $84,38 \%$ \\
\hline
\end{tabular}




\begin{tabular}{|l|l|l|l|}
\hline \multirow{2}{*}{ No. } & \multirow{2}{*}{ Indikator } & \multicolumn{2}{|c|}{ Skor } \\
\cline { 3 - 4 } & Siklus 1 & Siklus 2 \\
\hline $\begin{array}{l}\text { dan memecahkan } \\
\text { masalah }\end{array}$ & & \\
\hline \multicolumn{2}{|l|}{ Skor rata-rata } & $76,14 \%$ & $83,13 \%$ \\
\hline
\end{tabular}

Sumber: Data primer yang diolah

Berdasarkan data pada siklus I diperoleh skor sebesar $76,14 \%$. Pada siklus II mengalami perubahan dimana semua indikator sudah mencapai kriteria minimal yang ditentukan dan rata-rata skor semua indikator sebesar $83,13 \%$.

\section{4) Data Angket Respon Siswa}

Peneliti menggunakan angket untuk mengetahui Respon Siswa terhadap Implementasi Model Pembelajaran Kooperatif Tipe TAI dalam pembelajaran akuntansi. Penelitian ini dikatakan mendapatkan respon positif apabila minimal $75 \%$ dari jumlah siswa di kelas mencapai respon yang sangat positif dan respon yang positif.

Tabel 6. Hasil Data Angket Respon Siswa

\begin{tabular}{|c|c|c|}
\hline Kategori & $\begin{array}{c}\text { Jumlah } \\
\text { Siswa }\end{array}$ & Persentase \\
\hline $\begin{array}{c}\text { Sangat } \\
\text { Positif }\end{array}$ & 21 & $65,63 \%$ \\
\hline Positif & 10 & $31,25 \%$ \\
\hline Negatif & 1 & $3,13 \%$ \\
\hline $\begin{array}{c}\text { Sangat } \\
\text { Negatif }\end{array}$ & 0 & $0 \%$ \\
\hline Jumlah & 32 & $100 \%$ \\
\hline
\end{tabular}

Sumber: Data primer yang diolah

Tabel di atas merupakan skor yang diperoleh dari angket Respon Siswa terhadap Implementasi Model Pembelajaran Kooperatif Tipe TAI yang telah diisi oleh siswa. Dari hasil tersebut terlihat bahwa jumlah siswa yang memberikan respon yang sangat positif dan atau positif pada skor angketnya sebanyak 31 siswa atau 96,88\% dari jumlah siswa di kelas.

\section{Pembahasan Hasil Penelitian}

Dalam

pelaksanaan

pembelajaran dengan Model

Pembelajaran Kooperatif Tipe

TAI baik pada siklus I maupun siklus

II siswa menunjukkan aktivitasaktivitas yang mencerminkan adanya motivasi untuk belajar. Data peningkatan dapat dilihat melalui grafik berikut:

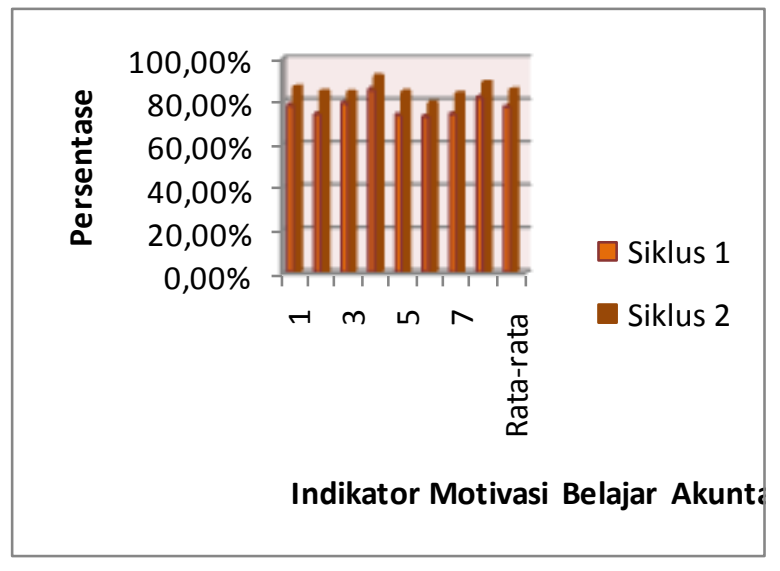

Gambar 1. Grafik Perbandingan Skor Motivasi Belajar

Berdasarkan data di atas dilihat bahwa terjadi peningkatan skor motivasi belajar akuntansi dari sebelum siklus I ke siklus II 7,78\%. Pada setiap indikator motivasi belajar akuntansi juga mengalami peningkatan seluruhnya. Sehingga dapat disimpulkan bahwa motivasi belajar akuntansi siswa mengalami peningkatan disetiap siklusnya.

Pada setiap akhir siklus dilakukan penyebaran angket Motivasi Belajar Akuntansi. Motivasi Belajar 
Akuntansi dengan Implementasi Model Pembelajaran Kooperatif Tipe TAI pada kelas X Akuntansi 3 SMK negeri 1 Godean Tahun Ajaran 2013/2014 mengalami peningkatan. Data peningkatan dapat dilihat melalui grafik berikut:

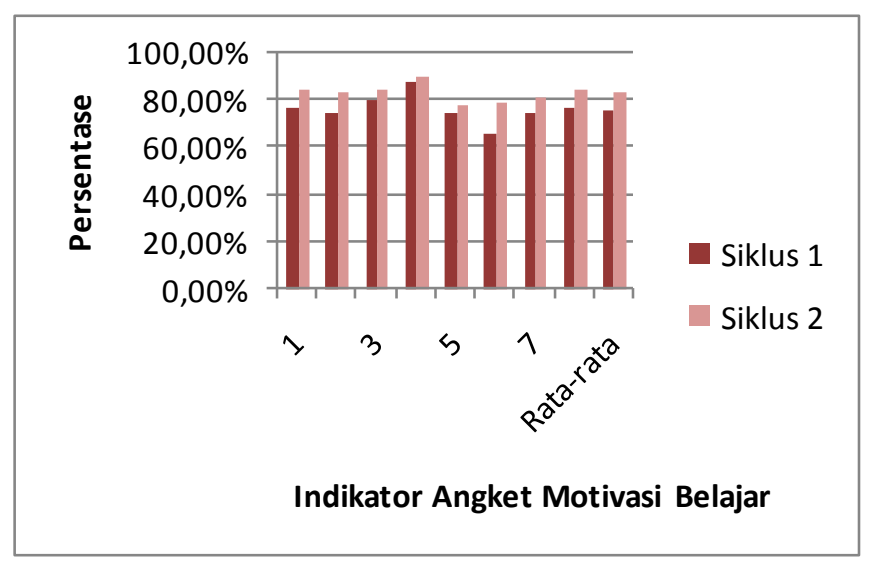

Gambar 2. Grafik Angket Motivasi Belajar

Berikut ini penarikan kesimpulan Motivasi Belajar Akuntansi berdasarkan indikatorindikator yang melingkupinya:

1. Indikator tekun menghadapi tugas

Dalam hasil observasi dapat dilihat terjadi peningkatan Motivasi Belajar Akuntansi pada siklus I ke siklus II sebesar 8,33\%. Peningkatan skor Motivasi Belajar Akuntansi siswa juga ditunjukkan dari data angket dimana terjadi peningkatan sebesar 7,3\% dari siklus I ke siklus II. Pembelajaran ini dapat menambah kemampuan berpikir siswa dari berbagai sumber baik dari buku maupun dari temanteman dalam kelompoknya sehingga siswa tidak hanya bergantung pada guru. Hal ini sesuai dengan pendapat Wina Sanjaya (2011: 249) mengenai keunggulan pembelajaran kooperatif yaitu siswa tidak bergantung hanya kepada guru, akan tetapi dapat menambah kemampuan berfikir sendiri, menemukan informasi dari berbagai sumber dan belajar dari siswa lain.

2. Indikator ulet menghadapi kesulitan Dalam hasil observasi dapat dilihat terjadi peningkatan Motivasi Belajar Akuntansi pada siklus I ke siklus II sebesar 10,42\%. Dalam data angket juga mengalami peningkatan Motivasi Belajar Akuntansi dari siklus I ke siklus II yaitu sebesar 9,37\%. Peningkatan ini terjadi karena siswa sudah mulai terbiasa dan berani bertanya untuk menyamakan pendapat dengan guru maupun untuk mencari pemecahan masalah dengan bertanya kepada guru serta bertanya kepada siswa lain sehingga keuletan siswa meningkat. Hal ini sesuai dengan pendapat Wina Sanjaya (2011: 250) mengenai keunggulan pembelajaran kooperatif yaitu interaksi selama pembelajaran kooperatif dapat meningkatkan motivasi dan memberikan rangsangan untuk berpikir.

3. Indikator memiliki minat terhadap pelajaran

Dalam hasil observasi dapat dilihat terjadi peningkatan Motivasi Belajar Akuntansi pada siklus I ke siklus II sebesar $4,86 \%$. Peningkatan data tersebut selaras dengan data yang diperoleh dari angket. Pada angket peningkatan skor sebesar $3,74 \%$. Penyampaian materi mentggunakan modul pembelajaran dapat menarik perhatian siswa sehingga siswa lebih fokus untuk memperhatikan 
penjelasan guru dan menimbulkan komunikasi dua arah antara siswa dengan guru. Dengan demikian siswa menjadi lebih tertarik mengenai materi yang disampaikan oleh guru sehingga Motivasi Belajar Akuntansi siswa meningkat. Hal ini sesuai dengan pendapat Hamzah B. Uno (2008: 23) yang menyebutkan salah satu faktor yang mempengaruhi motivasi belajar yaitu faktor eksterinsik berupa kegiatan belajar yang menarik.

4. Indikator lebih senang bekerja mandiri Dalam hasil observasi dapat dilihat terjadi peningkatan Motivasi Belajar Akuntansi pada siklus I ke siklus II sebesar 6,25\%. Dalam data angket juga mengalami peningkatan Motivasi Belajar Akuntansi dari siklus I ke siklus II yaitu sebesar 2,04\%. Dengan dilakukannya penerapan pembelajaran kooperatif tipe TAI mampu memberikan dampak positif bagi siswa untuk menyelesaikan tugas individu secara mandari karena siswa sudah mempelajari materi sebelum pembelajaran dimulai.

5. Indikator cepat bosan pada tugas-tugas rutin

Dalam hasil observasi dapat dilihat terjadi peningkatan Motivasi Belajar Akuntansi pada siklus I ke siklus II sebesar 10,94\%. Dalam data angket juga mengalami peningkatan Motivasi Belajar Akuntansi dari siklus I ke siklus II yaitu sebesar $6,37 \%$. Peningkatan ini dikarenakan siswa sudah mulai tertarik dan tertantang dengan tugas- tugas rutin yang diberikan oleh guru. Hal ini dikarenakan dengan penerapan model pembelajaraan kooperatif tipe TAI, siswa dituntut untuk bekerjasama mengerjakan tugas yang diberikan oleh guru.

6. Indikator dapat mempertahankan pendapatnya

Dalam hasil observasi dapat dilihat terjadi peningkatan Motivasi Belajar Akuntansi pada siklus I ke siklus II sebesar 6,25\%. Dalam data angket juga mengalami peningkatan Motivasi Belajar Akuntansi dari siklus I ke siklus II yaitu sebesar 13,28\%. Dengan dilakukannya penerapan pembelajaran kooperatif tipe TAI, siswa menjadi lebih aktif dalam memberikan pendapatnya dalam diskusi.

7. Indikator tidak mudah melepas hal yang diyakini

Dalam hasil observasi dapat dilihat terjadi peningkatan Motivasi Belajar Akuntansi pada siklus I ke siklus II sebesar 9,37\%. Dalam data angket juga mengalami peningkatan Motivasi Belajar Akuntansi dari siklus I ke siklus II yaitu sebesar $6,77 \%$. Siswa menjadi lebih mantap dalam menyampaikan pendapatnya atas hasil pekerjaan yang dikerjakannya secara berkelompok. Rasa mantap ini didapatkan karena merupakan hasil diskusi bersama sehingga didapatkan hasil jawaban yang meyakinkan. Siswa dapat mempertahankan pendapatnya karena siswa telah memahami sendiri materi yang dibahas.

8. Indikator senang mencari dan memecahkan masalah 
Dalam hasil observasi dapat dilihat terjadi peningkatan Motivasi Belajar Akuntansi pada siklus I ke siklus II sebesar 6,77\%. Dalam data angket juga mengalami peningkatan Motivasi Belajar Akuntansi dari siklus I ke siklus II yaitu sebesar 7,04\%. Siswa semakin senang jika harus mengerjakan soal karena siswa yang paling cepat dan dapat menjawab dengan benar akan mendapatkan hadiah. Dalam hal ini siswa semakin memiliki rasa tanggung jawab untuk mengerjakan tugas-tugas yang diberikan oleh guru. Hal ini sesuai dengan pendapat Wina Sanjaya (2011: 249) mengenai keunggulan pembelajaran kooperatif yaitu pembelajaran kooperatif dapat memberdayakan setiap siswa untuk lebih bertanggung jawab dalam belajar.

Dari pembahasan di atas dapat disimpulkan bahwa TAI dapat memotivasi siswa agar saling mendukung dan membantu satu sama lain dalam menguasai kemampuan (belajar) yang diajarkan oleh guru. Hal ini sesuai pendapat Robert E. Slavin (2008: 191) bahwa dengan pembelajaran TAI, para siswa akan termotivasi untuk mempelajari materimateri yang diberikan dengan cepat dan akurat, dan tidak akan bisa berbuat curang atau menemukan jalan pintas. Oleh karena itu, dengan ini telah terbukti bahwa dengan Implementasi Model Pembelajaran Kooperatif Tipe Team Accelerated Instruction (TAI) dapat meningkatkan Motivasi Belajar Akuntansi pada Kompentansi Dasar Dana Kas Kecil Siswa Kelas X
Akuntansi 3 SMK Negeri 1 Godean

Tahun Ajaran 2013/2014.

Penelitian ini dikatakan akan memperoleh respon positif siswa apabila minimal $75 \%$ dari jumlah siswa dikelas mencapai respon yang sangat positif dan atau respon positif terhadap implementasi pembelajaran kooperatif tipe TAI. Berikut grafik respon siswa dapat dilihat di bawah ini:



Gambar 3. Respon Siswa

Berdasarkan pada grafik di atas dapat disimpulkan bahwa implementasi pembelajaran kooperatif tipe TAI pada pembelajaran akuntansi mendapatkan respon yang sangat positif dari siswa. Hal tersebut diartikan bahwa siswa merasa nyaman, merasa senang, dan bergairah dengan pengimplementasian pembelajaran kooperatif tipe TAI pada pembelajaran akuntansi.

\section{SIMPULAN DAN SARAN}

\section{Simpulan}

1. Implementasi Model Pembelajaran Kooperatif Tipe TAI

Berdasarkan hasil penelitian dan pembahasan pada bab IV dapat disimpulkan bahwa Implementasi 
Model Pembelajaran Kooperatif Tipe Team Accelerated Instruction (TAI) dapat Meningkatkan Motivasi Belajar Akuntansi pada Kompetensi Dasar Dana Kas Kecil Siswa Kelas X Akuntansi 3 Tahun Ajaran 2013/2014 yang dibuktikan dengan adanya peningkatan persentase skor motivasi belajar akuntansi yang diambil melalui observasi dengan lembar observasi diperoleh skor sebesar $69,38 \%$ sebelum implementasi model pembelajaran kooperatif tipe TAI kemudian meningkat menjadi $77,40 \%$ pada siklus I. Pada siklus II terjadi peningkatan pula yaitu sebesar 7,78\% atau diperoleh skor sebesar $85,18 \%$. Peningkatan motivasi belajar akuntansi secara individual pada siklus I terdapat $62,5 \%$ siswa dan meningkat pada siklus II menjadi $87,5 \%$ siswa. Selain itu, berdasarkan angket yang didistribusikan kepada siswa dapat disimpulkan bahwa terjadi peningkatan skor motivasi belajar akuntansi sebesar 6,99\% dimana skor pada siklus I sebesar $76,14 \%$ meningkat menjadi $83,13 \%$ pada siklus II. Dari data observasi dan angket yang diperoleh dapat disimpulkan bahwa dengan Implementasi Model Pembelajaran Kooperatif Tipe TAI dapat Meningkatkan Motivasi Belajar Akuntansi Siswa.

2. Respon Siswa terhadap Implementasi Model Pembelajaran Kooperatif Tipe TAI Implementasi Model Pembelajaran Kooperatif Tipe TAI mendapatkan respon positif siswa pada pembelajaran akuntansi. Berdasarkan berdasarkan angket yang didistribusikan kepada siswa bahwa
21 siswa atau $65,63 \%$ siswa mempunyai respon yang sangat positif, 10 siswa atau $31,25 \%$ siswa mempunyai respon positif, dan 1 siswa atau 3,13\% memberikan respon yang negatif. Dari hasil tersebut terlihat bahwa jumlah siswa yang memberikan respon sangat positif dan positif pada skor angketnya sebanyak 31 siswa atau $96,88 \%$ siswa dari jumlah seluruh siswa di kelas. Dari data angket yang diperoleh dapat disimpulkan bahwa dengan dilakukannya Implementasi Model Pembelajaran Kooperatif Tipe Team Accelerated Instruction (TAI) mendapatkan respon sangat positif dari siswa.

\section{Saran}

\section{Bagi Guru}

Guru dapat mencoba untuk melakukan implementasi model pembelajaran kooperatif tipe TAI pada kompetensi dasar yang lain yang diharapkan dapat memicu peningkatan keuletan siswa yang masih rendah dalam menghadapi kesulitan belajar sehingga siswa merasa senang dan puas dalam mengerjakan tugas yang diberikan oleh guru serta pada akhirnya siswa memiliki keinginan yang lebih besar untuk berhasil dalam belajar.

\section{Bagi Siswa}

Siswa perlu membiasakan diri untuk lebih banyak melakukan motivasi belajar guna memperoleh pemahaman materi yang lebih baik.

3. Bagi Peneliti Selanjutnya

Hasil penelitian ini berdasarkan delapan indikator. Oleh karena itu untuk penelitian lebih lanjut diharapkan dapat 
menambah indikator motivasi belajar agar diperoleh hasil yang mewakili motivasi belajar siswa.

\section{DAFTAR PUSTAKA}

Hamzah B. Uno. (2008). Perencanaan Pembelajaran. Jakarta: Bumi Aksara.

Muhibbin Syah. (2010). Psikologi Pendidikan dengan Pendekatan Baru. Badung: Remaja Rosdakarya.

Muhibbin Syah. (2011). Psikologi Belajar. Jakarta: Raja Grafindo Persada.

Mulyasa. (2007). Menjadi Guru Profesional Menciptakan Pembelajaran Kreatif \& Menyenangkan. Bandung: Remaja Rosdakarya.

Rusman. (2010). Model - Model Pembelajaran. Bandung : Rajawali Pers.

Slameto. (2010). Belajar dan Faktor Faktor yang Mempengaruhi. Jakarta : Bumi Aksara.

Slavin, Robert E. (2005). Cooperative Learning. Terjemahan Narulita Yusron. Bandung: Nusa Media.

Wina Sanjaya. (2012). Penelitian Tindakan Kelas. Jakarta: Kencana. 